\title{
Conducing the Cashless Revolution in Pakistan Using Enterprise Integration
}

\author{
Sania Zafar, Sidra Riaz, Waqas Mahmood \\ Department of Computer Science, Institute of Business Administration - IBA, Karachi, Pakistan \\ E-mail: szawan@khi.iba.edu.pk
}

Received: 24 July 2020; Accepted: 26 January 2021; Published: 08 August 2021

\begin{abstract}
The cashless revolution is changing the landscape of the banking industry in Pakistan. In addition to internet and phone banking, a major role is played by Fintech applications such as UPaisa, Easypaisa, and JazzCash. This paper aims to study the public perception of a cashless Pakistan and the potential of Pakistan to develop into a cashless economy. We conduct an exploratory survey to find out the needs, expectations, perceptions, and fears of the consumers associated with cashless technology, and then discuss various ways in which Pakistan can go completely cashless such as e-wallets, debit cards, and other digital payment systems. The results of the survey show a positive response of the public towards a cashless Pakistan. Several factors are identified that the public faces. These make the public reluctant to move to cashless technology. This paper will point these out, and suggest solutions to these problems; paving the path towards a cashless Pakistan.
\end{abstract}

Index Terms: Cashless, e-wallet, Fintech, plastic money, Enterprise integration

\section{Introduction}

The infrastructure for branchless banking is already in place with $34 \%$ of people using cell phones equipped with a broadband connection; however, only $21 \%$ of Pakistani adults are utilizing financial services [1]. Pakistan is rapidly moving towards a digital-first country and it is expected to be the fourth-largest digital economy by 2030 [1]. Digital wallets are a relatively new technology with a consumer base of 27.3 million, growing by $87 \%$ every year. Some of the major players of digital wallets are Easypaisa, UPaisa, JazzCash, UBL Omni, and SimSim; the majority belonging to the telecom industry. Looking at the current situation the question is: how far is Pakistan from becoming cashless?

A cashless economy encourages electronic payment mechanisms such as debit cards, credit cards, phone banking, internet banking, Point-of-Sales, and digital wallets, simultaneously minimizing cash handling and cash-oriented transactions. There are several benefits to this model of the economy [2]. The increased use of digital systems would prevent users from carrying large amounts of cash, reducing the risks associated with cash handling. Businesses and the government will save millions of rupees as they will not need to bear the cost associated with cash management [3]. More employment opportunities are expected with the rise in digital payment systems; they will increase the efficiency of business and services as well as decrease cost.

And although there are several problems associated with a cashless economy, these problems can be solved and the benefits far outweigh the disadvantages. For instance, the low-income population is at risk of financial exclusion [4] by being unable to access these financial services. This is because many of them do not have access to cell phones or other mobile devices. There is also unawareness of the existence of such services.

Pakistan can save \$1.5 million if the people move towards digital transaction systems, just from Karachi alone [5]. Technology has played a major role in revolutionizing the economy, it is expected that 90 percent of the population can become cashless by using the digital payment systems available. Currently, only 10 percent of Karachi is utilizing those services [5].

Reports from State Bank of Pakistan have claimed a marked transition in users from cash to e-payments systems. The huge amount of goods and services sold and bought online through various websites, such as OLX, Daraz, Zameen.com, and Pakwheels prove that people find internet services convenient and are moving towards them. Some of these websites also offer e-cash methods such as JazzCash, which are preferred by several people [6].

There are certain problems people face when using digital payment systems that discourage them from relying on them. The four major ones being, limited access to digital services, many services are not consumer-friendly, a cybersecurity threat associated with these digital payments, and lastly, there is limited infrastructure to provide these services to the public. 
In the current system cash and cashless services co-exist. This paper aims to gather and report statistical data on the public's views on cashless technologies: the problems they face, their reasons for preferring paper currency, and negative notions associated with cashless technology. The paper then goes on to discuss these problems and posit potential solutions to these problems. Solving these problems and will enable Pakistan to move towards a cashless economy.

\section{Background}

In recent years, Pakistan has witnessed a rise in the surge of digital innovation. With the Federal Government's pronouncement to demonetize all old design banknotes of Pakistan in 2015, it was no wonder that it ensued. The decision to discontinue the previous currency and introduce a completely new one was carried out to enhance the security, durability and aesthetic design of the Pakistani currency [7]. While that may be true, it places the cash that the public possesses into a precarious position. Therefore, the direct and obvious outcome of demonetization would be that the public turned to digitization to look for solutions there. In their study, [8] they analyze the impact of demonetization on digitization. They concluded that with the growing uncertainty of cash transactions, there was a considerable increase in different forms of digital payments like debit and credit cards and e-wallets.

E-wallet is the digital counterpart of a wallet wherein a customer can stock up on virtual money to use when required. It is the favored form of payment for online delivery in the e-commerce sector but is also gaining popularity in the service sector. For example, ride-hailing services like Uber and Careem encourage the use of their mobile wallet. A study conducted by [9] on the growing acceptance of e-wallets, found that e-wallets tend to be considered to have secured privacy and transaction. More than $95 \%$ of the respondents had at least one application on their phone which supported e-payments, while $30 \%$ of them actively used e-wallets for their regular transactions.

Focusing on the use of credit and debit cards in Pakistan, referred to as "plastic money", it was revealed that debit cards are the more favored method of payment compared to credit cards. This might be because credit cards require the additional payment of the balance at the end of each month. It also showed that males are more likely to use plastic money than females [10]. The results of this study prove that Pakistan needs to concentrate on providing convenient solutions to its citizens to get them to adopt the digital route.

Researching on the potential for an emerging market in FinTech in Pakistan, [11] noted that there were various concerns on why Pakistan is uncertain about fully embracing the digital world. The first and foremost concern is the rise of cyber threats, ransomware and cyber breach of customer data, which has naturally inclined some to be wary about the different forms of digital payment solutions gradually being introduced to them [12]. The announcement by Careem last year of a breach in their customer data was a huge cause for alarm, further implanting the idea that for people to adopt cashless transactions completely, Pakistan would have to work on its cybersecurity.

Leading the upcoming generation of youth towards design thinking and innovation will give Pakistan a chance to churn out creative solutions geared towards secure digital transactions [13].

\section{Motivation}

This paper aims to analyze the response of public on cashless technologies, the limitations, and problems associated with such technologies and solutions to these problems, ways that these inhibitions can be removed so that the public can be motivated to move towards a cashless Pakistan. By exploring these domains, it is made possible to understand what are the factors contributing to the current state of this hybrid, "paper-digital economy, which of these will prove to be conducive and which of these are resistive, in the desired shift to a cashless economy.

The main objectives are:

- To survey existing cashless technologies in Pakistan.

- To investigate the effect of technical factors on the usage of e-payment systems.

- To investigate effects of bank-related factors on the usage of e-payment systems.

- To study transaction-related factors such as convenient, secure transactions on e-payment systems.

\section{Literature Review}

For a long time, conventional banking served as the central method of the payment system. Ask anyone about a few years ago and they would narrate their salary being deposited into their bank account or using cash or cheques to pay the utility bills and so on. Invariably, the banking system was essential to most of the payment transactions.

The landscape has now changed to give way to newer avenues of payment, which include PayPal, a peer-to-peer transaction system, mobile money transfers services such as Telenor Easypaisa and JazzCash, and cryptocurrency exchanges like Bitcoin. These alternate methods of transactions make up the shadow payment system [17]. 
On the downside, the way the shadow payment system works to make it susceptible to cyber-attacks of various forms. Phishing, ransomware and identity theft are just a few of the cyber threats gaining momentum in the recent era of digitization, making users wary of adopting shadow payment systems.

[14] Tries to understand the popularity of plastic money (debit and credit cards) and its usage from a consumer's perspective in India. They try to figure out how convenient does the public find these cashless methods and what are the problems faced by them when adopting these methods. The results of this paper signify that people prefer to use plastic money instead of cash in daily usage as well as online transactions. It observed education as a very important factor when using these cashless methods. The people preferred these methods because of several factors such as ease of use, convenient to use at any time and any place, it also reduces the risk associated with carrying money. Besides, the person is no more dependent on bank timings or bank branches.

[15] Talks about the banking industry in Pakistan and how has cashless banking benefited the banking industry. It talks about four most popular cashless methods; ATMs, POS machines, call center banking and mobile banking and studies its impact on Return on Equity using data from 2nd quarter of 2007 to 4th quarter of 2014. It shows a positive relation with P-O-S transactions and mobile-based transactions and a negative relation with call-center transactions and ATM transaction. It identifies 'trust' as the major reason for consumers to not use call center services. Consumers also fear that there might be data leaks, which may cause a lot of financial damage. It suggests creating awareness about internet banking because it reduces cost on both ends. It also identified problems with ATM transactions, the card is stuck in the machines, ATM server links being down leaving the consumer frustrated and reluctant to use these services.

[16] Proposes a new research model for analyzing factors influencing internet banking. It suggests that if users are provided with personalized internet banking solutions they are expected to adopt it much quicker. It also suggests that people find it easier to use internet banking when it acts as a standalone payment system that does multiple things, for instance paying utility bills, card payments, and school fee payment. Compatibility of user lifestyle and work style is an important factor in user adopting internet banking.

[2] This paper is the major motivation behind our paper; this paper aims at capturing public perception about the cashless economy in India. The data from the survey was collected and analyzed, according to the results, people are increasingly moving towards cashless transactions, however there are few factors which compel them to use cash, such factors include security problems, trust issues, lack of technology suited to user needs and late reimbursement of cash in case of failed transactions. The study states that India needs to change people's perception to transition completely into a cashless economy.

[18] et al. in their research discuss the popular forms of cashless transactions which are being adopted throughout the world. Cheques started to gain volume quite some time back and have been a common mode of non-cashless transfer since then. The decline in its popularity is only due to the growing convenience of Internet banking and campaigns aimed at spreading awareness about e-payments. E-money consists of some prepaid amount stored in a device which can be used to make payments. Examples include mobile balance top-up using prepaid services of the mobile service provider. Payment cards, also known as "plastic money" are another popular form of cashless transactions. However, unlike most other modes, it relies on the banking system to serve as the backbone for its use.

Cryptocurrency is based on the concept of digital coins, which serve as electronic receipts. Bitcoin is the most popular platform of cryptocurrency, sometimes interchangeably used with it.

Cryptocurrency has no central issuing or regulatory authority; therefore, all transactions are done directly without involving any authority in the middle. It is independent of any jurisdiction around the world, making it virtually untraceable [19]. This has been highlighted as being an attractive workaround for those who are reluctant to adopt cashless systems due to the fear of cyber-attacks.

In their research on E-wallets as a mode of payment, [20] et al. suggest the use of various forms of security features to enhance its usage as well as reduce the risk of cyber-attacks. They also present the innovative idea of echeques; since cheques are already widely adopted, it would be easier and more convenient to switch to an electronic version of it. The e-cheques would be secured by digital signatures. Intelligent cards would be used to store these signatures through coding keys. ID number would activate the card. As an added security, it could also use biometric verification as an added layer of security.

\section{Research Methodology}

Primary data was collected for this study using a comprehensive survey. Google forms was used to make the questionnaire. It was based on two previous questionnaires found on survey monkey [21], [2], and some questions were added for the existing digital wallet technologies in Pakistan. There were twenty-three questions, out of which four were about the respondents' profile.

There were 113 responses, $32 \%$ of those were males and $68 \%$ of them were females. Google forms built-in reporting was used to analyze the factors affecting people moving towards a cashless Pakistan. The survey was aimed at people of all age groups and income classes; it was circulated through Facebook as well as WhatsApp. 


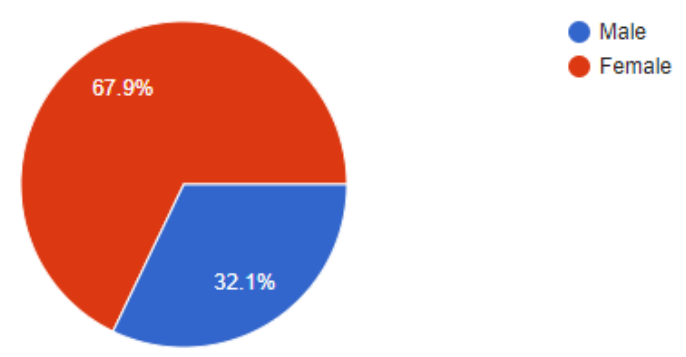

Fig 1. More than half of the respondents were female

\section{Results}

About 54\% of the respondents fell in the 18-24 age range, while $32 \%$ were in the $25-34$ range. Therefore, it is assumed that since $86 \%$ of respondents' ages range from $18-34$, the results of this survey apply mainly to the youth of Pakistan.

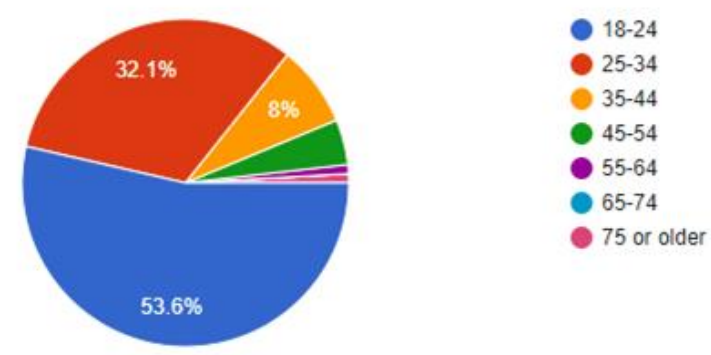

Fig 2. Age brackets of survey respondents.

Most of the respondents, about $55 \%$ of them, are working as employees while only about $11 \%$ are self-employed or run their own business.

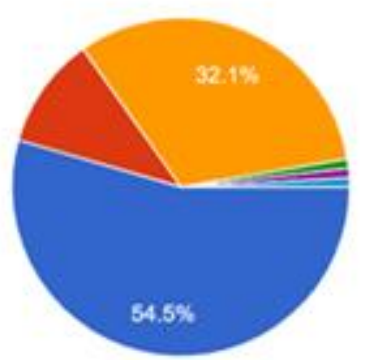

Employee

- Self Employed/Business

Other

- Student

- Unemployed. Student

Online job

Fig 3. Occupations of respondents

The salary ranges of the respondents presented one of the most varied results in the survey, with $27 \%$ of the respondents earning below 20,000, 30\% earning between Rs20,000-40,000, $12 \%$ earning between Rs40,000-60,000 while $21 \%$ earned above Rs60,000 each month. 


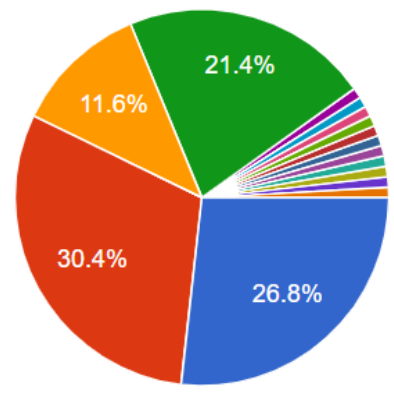

Below 20,000

$20,000-40,000$

$40,000-60,000$

Above 60,000

Dependent

10,000

I don't earn

Unemployed

$\Delta 1 / 2 \nabla$

Fig 4. Varied monthly incomes of respondents

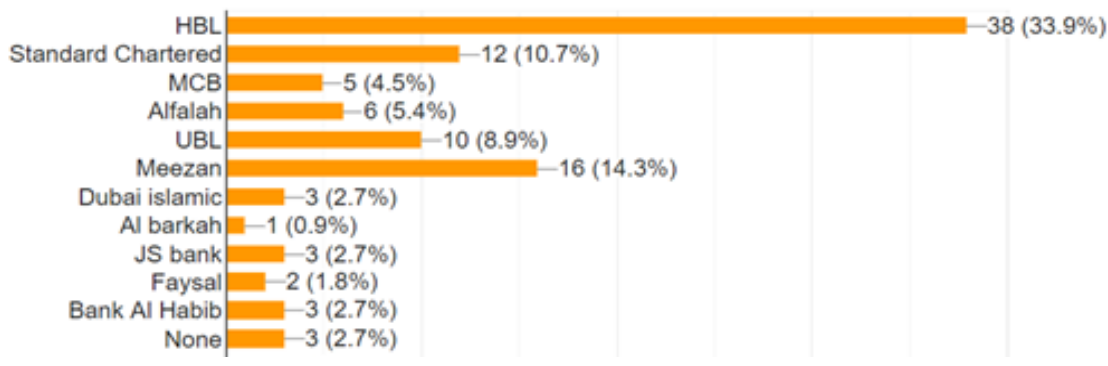

Fig 5. Preferred banks for personal accounts by respondents.

Habib Bank Limited seemed to be the most popular bank with $34 \%$ of the respondents having an account in it. Other banks with a notable number of accounts of respondents were Standard Chartered, Meezan Bank, Muslim Commercial Bank, United Bank Limited and Alfalah Bank.

Only about $19 \%$ of the respondents were completely in favor of commercial banks while $68 \%$ of them, making up the majority, were only just slightly in favor of them.

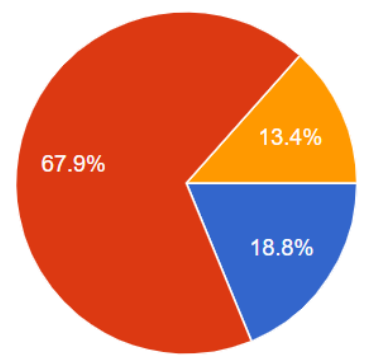

Strongly in favou

Somewhat in favour

Somewhat not in favour

Strongly not in favour

Fig.6. Preference for commercial banks

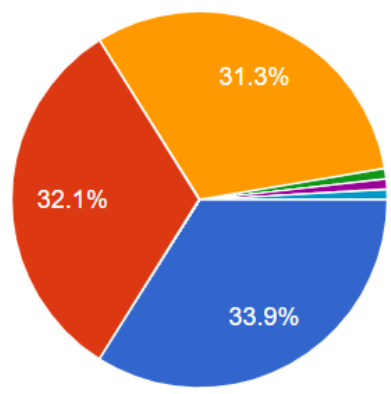

Credit Card

Cash

Debit Card

Online Transactions (electronic Banking)

QR Payment

No account

Fig 7. Preferred form of payment 
According to the survey, it was revealed that credit cards are the most preferred payment method with $34 \%$ respondents, while cash and debit card was the least preferred payment method for $32 \%$ and $31 \%$ respondents respectively.

$86 \%$ of them also said they used mobile money about 0-5 times a day to pay for goods and services while $13 \%$ of them considered themselves regular daily users of mobile money.

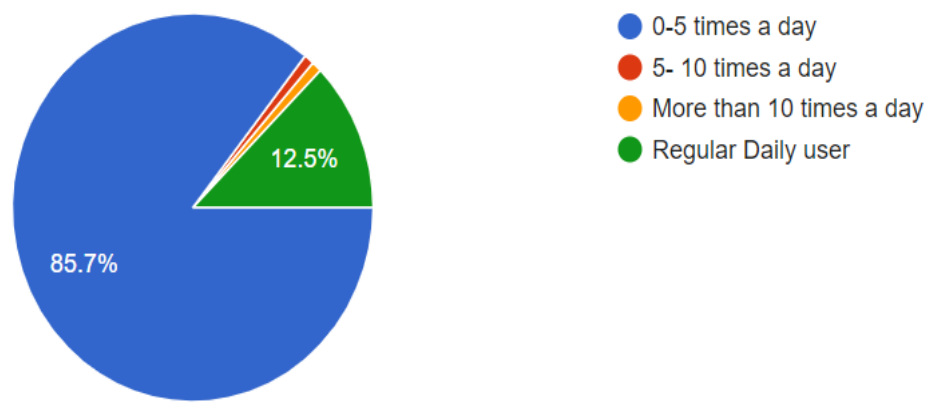

Fig 8. Frequency of use of mobile money

Interestingly, about $75 \%$ of them also claimed to use bank cards around $0-5$ times a day to pay for goods and services while $17 \%$ said they were regular daily users of this technology.

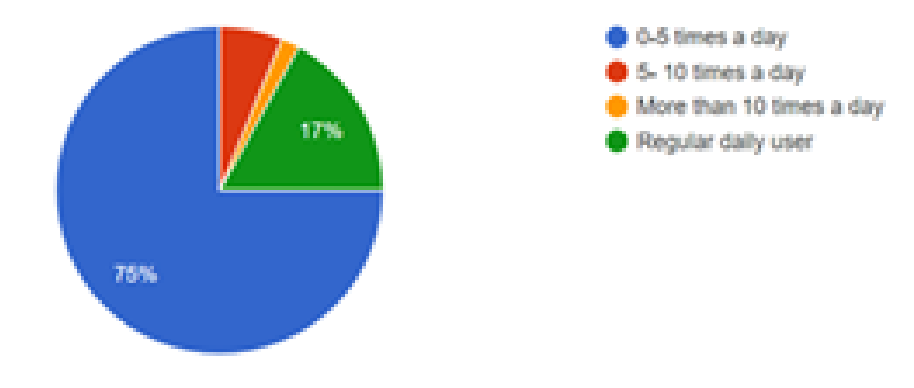

Fig 9. Frequency of use of bank cards

The respondents were conflicted about the payment method they would prefer for regular use with 53\% of them preferring cash and $45 \%$ preferring to use digital money, even though $48 \%$ of them considered digital money risky, while $35 \%$ didn't.
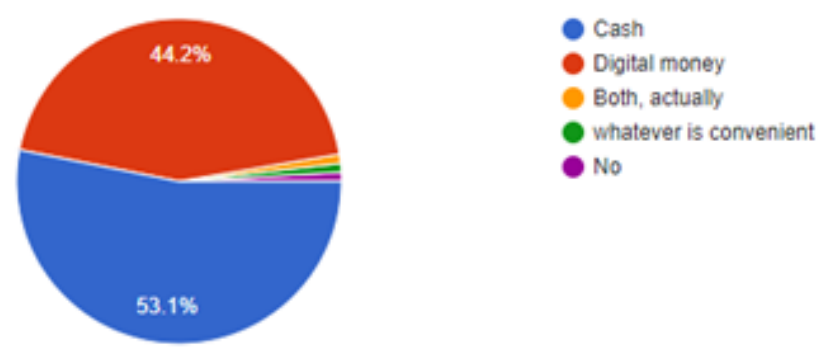

Fig 10. Preference for cash vs digital money

Over $53 \%$ of the respondents said they would like to see Pakistan going completely cashless, while $28 \%$ would not and $20 \%$ were not sure about it. 


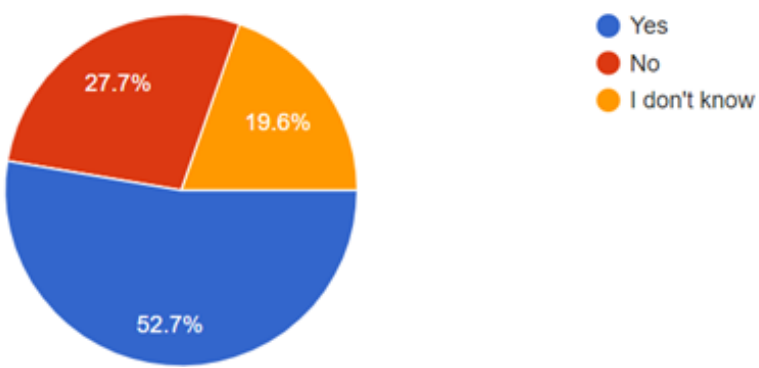

Fig 11. Support for cashless Pakistan

Among a current lot of existing cashless technologies, Internet banking, phone banking, Telenor Easypaisa and JazzCash were the most popular ones being used. However, about 55\% of respondents said they still used cash to pay their utility and other bills, such as Careem and Uber fares, even with their convenient cashless technologies.

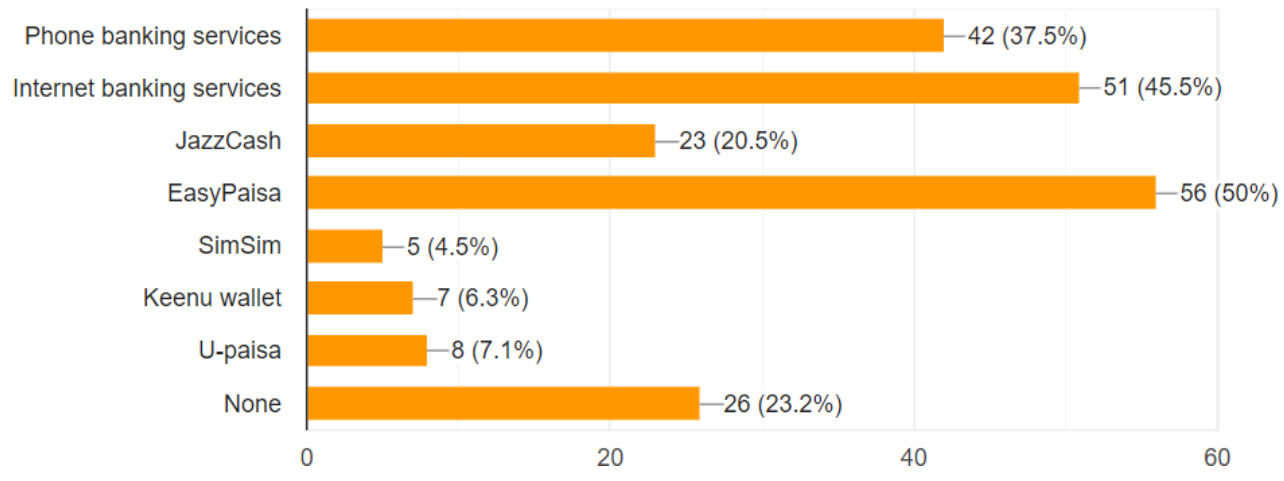

Fig 12. Popular methods of cashless transactions used

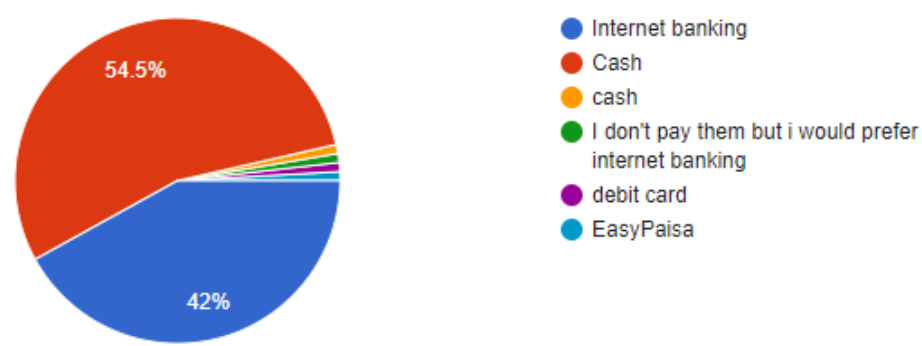

Fig 13. Preferred methods for the payment of utility bills

\section{Discussion and Analysis}

The results of the survey gave an insight into the mindset of the consumers on why cashless technology in Pakistan has not gained enough popularity and support.

We have thus identified the factors affecting the adoption of cashless technology in Pakistan:

- The learning-curve in adopting these technological advancements has made the people believe cashless methods are complicated. Previous generations did not enter the world to see mobile phones as common as light bulbs.

- Most of the rural and even urban population of Pakistan suffers from having lack of technical knowledge about the latest technologies. This results in $85 \%$ of respondents believing this would make people unable to perform cashless transactions easily. 


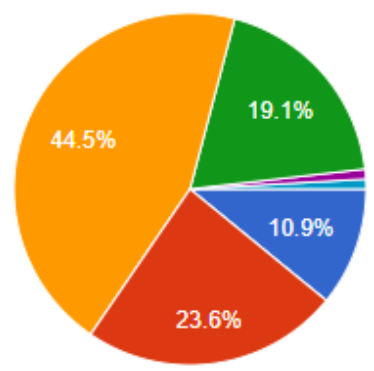

Strongly Agree

Agree

Neutral

Disagree

Strongly Disagree

disagree

Fig 14. Current cashless transaction methods are complicated

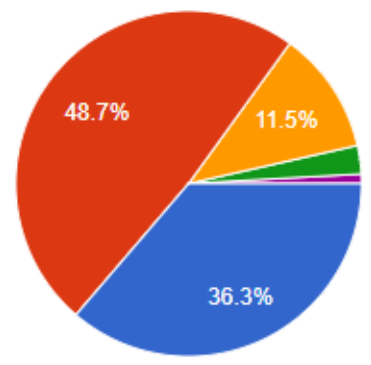

Strongly Agree

Agree

Neutral

Disagree

Strongly Disagree

Fig 14. Lack of technical knowledge acts as a barrier

- Even though about $75 \%$ respondents seemed to think that cashless transactions provided more convenience than traditional methods, the security threat of disclosing their personal and financial information online has made them reluctant to fully adopt it.
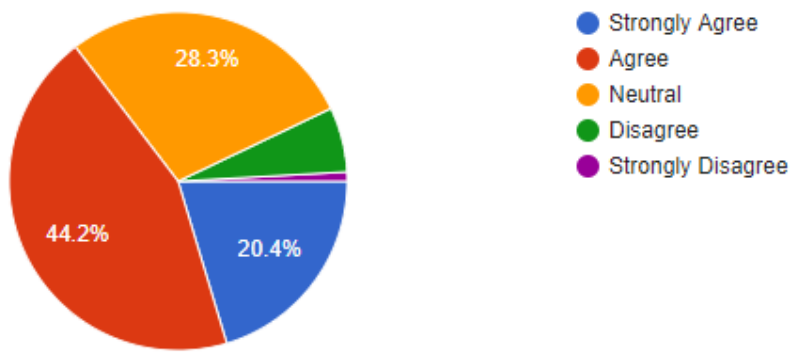

Fig 16. Financial Disclosure of Information prevents the use of cashless methods

- $69 \%$ of the respondents agreed that late reimbursement of failed transactions prevents them from using cashless technology. The delay in reimbursement induces fear of loss of money in the customer, which makes them feel frustrated and angry.
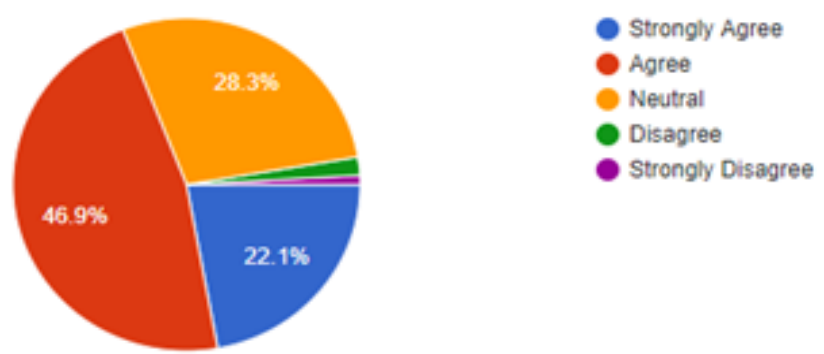

Fig 17. Delayed reimbursement of failed transactions prevents the use of cashless methods

- About $61 \%$ of people considered the limits on cashless transactions in Pakistan a factor impeding the adoption of cashless methods. This suggests that the current transactional limits are similar for everyone and not tailored according to the usage of their consumer. 


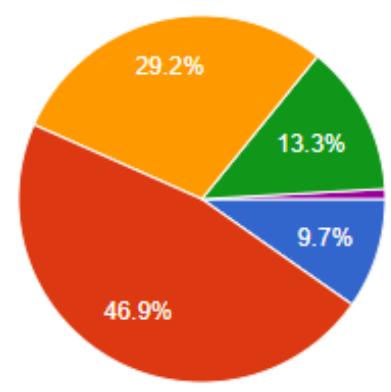

Strongly Agree

Agree

Neutral

Disagree

Strongly Disagree

Fig 18. Limits on cashless transactions

\section{Comparison of Results}

Some of the questions in our survey were taken from the paper which forms the main motivation for this research [1]. Here we compare the results of the previous research conducted in India, with our responses from Pakistan. The results of the comparison are shown in Table 1.

Both of the researches agree that the convenience of a cashless transaction is a major reason for its preference. About $71 \%$ of the people in the previous research think that digital methods are risky, however, current research suggests approximately half of the people think that cashless methods are not that risky.

About $50 \%$ of people in the previous research find current digital methods, difficult to use. Current research suggests that people are unaffected by the complication of digital methods. Current research strongly suggests that a lack of technical knowledge remains a crucial barrier in adopting cashless methods, while $22 \%$ of people in the previous studied disagreed with lack of technical knowledge being a major issue.

More people in the current research believe that limits on cashless methods, delayed reimbursement of failed payments and fear of disclosure of financial information are reasons stopping them from moving towards completely cashless. In contrast, the results showed that the youth of Pakistan is more than willing to adopt cashless methods, provided some of the issues are addressed.

\section{Conclusion}

The results reveal, that while the majority of the people are in favor of a cashless Pakistan, most of them are not using the current cashless technologies. There is a certain kind of stigma attached to cashless technologies that compel the public to still use cash.

Major problems faced by people when using cashless technologies are the difficulty of use, security problems, lack of awareness about these technologies, late reimbursement of failed transactions and lack of trust while sharing their financial information. Positive perceptions include, people, find cashless methods convenient and would like Pakistan to develop into a cashless economy.

The government and banking industry needs to understand the inhibitions faced by the public and promote these cashless services by gaining the public trust in these technologies and by attaching incentives to them so that we can move forward towards becoming a cashless society.

\section{Future Work}

This paper talks about a cashless economy within a single country however there is a need for something, which is central and unaffected by international boundaries. There is a need for a single currency and a global central bank in place; this would solve problems of integration faced due to different currencies and Fintech technology bringing a revolution worldwide. Moreover, further research in the Pakistani context can be conducted based on the data collected and analyzed. These facts and figures provide firm grounding about the troubles faced by people while conducting transactions. Further research can use these as the starting point, and innovate to solve these problems, fueling the engines of the Cashless Revolution in Pakistan. 
Table 1. Comparison of current research with previous research

\begin{tabular}{|c|c|c|}
\hline Questions & Previous Research & Current Research \\
\hline \multicolumn{3}{|c|}{ Convenience of Cashless Transactions } \\
\hline Strongly Agree & $23.08 \%$ & $18.60 \%$ \\
\hline Agree & $49.74 \%$ & $55.80 \%$ \\
\hline Neutral & $6.15 \%$ & $22.10 \%$ \\
\hline Disagree & $15.90 \%$ & $2.70 \%$ \\
\hline Strongly Disagree & $5.30 \%$ & $0.90 \%$ \\
\hline \multicolumn{3}{|c|}{ Cashless Methods are Risky } \\
\hline Yes & $70.77 \%$ & $47.80 \%$ \\
\hline No & $22.56 \%$ & $34.50 \%$ \\
\hline I don’t know & $6.67 \%$ & $17.70 \%$ \\
\hline \multicolumn{3}{|c|}{ Complicated Transaction Procedures } \\
\hline Strongly Agree & $32.82 \%$ & $10.90 \%$ \\
\hline Agree & $26.67 \%$ & $23.60 \%$ \\
\hline Neutral & $13.33 \%$ & $44.50 \%$ \\
\hline Disagree & $17.95 \%$ & $20.00 \%$ \\
\hline Strongly Disagree & $9.23 \%$ & $0.90 \%$ \\
\hline \multicolumn{3}{|c|}{ Lack of Technical Knowledge to use cashless methods } \\
\hline Strongly Agree & $20.00 \%$ & $36.30 \%$ \\
\hline Agree & $33.33 \%$ & $48.70 \%$ \\
\hline Neutral & $7.69 \%$ & $11.50 \%$ \\
\hline Disagree & $22.57 \%$ & $2.70 \%$ \\
\hline Strongly Disagree & $16.41 \%$ & $0.90 \%$ \\
\hline \multicolumn{3}{|c|}{ Problem Disclosing Financial Information } \\
\hline Strongly Agree & $19.49 \%$ & $20.40 \%$ \\
\hline Agree & $29.74 \%$ & $44.20 \%$ \\
\hline Neutral & $12.82 \%$ & $28.30 \%$ \\
\hline Disagree & $26.67 \%$ & $6.20 \%$ \\
\hline Strongly Disagree & $11.28 \%$ & $0.90 \%$ \\
\hline \multicolumn{3}{|c|}{ Limits on Cashless Transaction is a Problem } \\
\hline Strongly Agree & $17.95 \%$ & $9.70 \%$ \\
\hline Agree & $34.36 \%$ & $46.90 \%$ \\
\hline Neutral & $14.36 \%$ & $29.20 \%$ \\
\hline Disagree & $17.95 \%$ & $13.30 \%$ \\
\hline Strongly Disagree & $15.38 \%$ & $0.90 \%$ \\
\hline \multicolumn{3}{|c|}{ Delayed Reimbursement is a Problem } \\
\hline Strongly Agree & $18.97 \%$ & $22.10 \%$ \\
\hline Agree & $31.80 \%$ & $46.90 \%$ \\
\hline Neutral & $8.21 \%$ & $28.30 \%$ \\
\hline Disagree & $29.74 \%$ & $1.80 \%$ \\
\hline Strongly Disagree & $11.28 \%$ & $0.90 \%$ \\
\hline
\end{tabular}

\section{References}

[1] A. S. Sandhu, "Can the future of Pakistan be cashless?," 2019.

[2] V. Podile and P. R., "Public Perception on Cashless Transactions in India," Asian Journal of Research in Banking and Finance, vol. 7, no. 7, pp. 63-77, 2017.

[3] D. News, "Karachi offers huge potential for digital payment system: study," 7 August 2018. [Online]. Available: https://www.dawn.com/news/1425413. [Accessed 17 April 2019].

[4] M. A. Bayero, "Effects of Cashless Economy Policy on financial inclusion in Nigeria: An exploratory study," in Global Conference on Business \& Social Science-2014, Kuala Lumpur, 2015. 
[5] T. A. Saeed, "Cashless payments estimated to save Rs182 billion a year for Karachi: Visa," 7 August 2018. [Online]. Available: https://www.thenews.com.pk/print/351548-cashless-payments-estimated-to-save-rs182-billion-a-year-for-karachi-visa. [Accessed 17 April 2019].

[6] N. Desk, "Pakistan on its way to becoming a cashless economy," 13 March 2018. [Online]. Available: https://www.globalvillagespace.com/pakistan-on-its-way-to-becoming-a-cashless-economy/. [Accessed 2019].

[7] K. C. Balaji, "A Study on Demonetization and Its Impact on Cashless Transactions," International Journal of Advanced Scientific Research \& Development, vol. 04, no. 03, pp. 58-64, 2017.

[8] S. Agarwal, D. Basu, P. Ghosh, B. Pareek and J. Zhang, "Demonetization and Digitization," SSRN Electronic Journal, 472018.

[9] R. Varsha and M. Thulasiram, "Acceptance of e-wallet services: A study of consumer behavior," International Journal of Innovative Research in Management Studies, 2016.

[10] J. A. Qureshi, S. Baqai, M. A. Qureshi, S. Zulfikar and A. Bhutto, "International Journal of Economics and Financial Issues Consumers' Attitude towards Usage of Debit and Credit Cards: Evidences from the Digital Economy of Pakistan," International Journal of Economics and Financial Issues, vol. 8, no. 5, pp. 220-228, 2018.

[11] S. Kumail, A. Rizvi, B. Naqvi and F. Tanveer, "Is Pakistan Ready to Embrace Fintech Innovation?," 2018.

[12] D. W. Nongsiej and H. Debnath, "A study on the Impact of Demonetization," Journal of Management in Practice, vol. 2, no. 1, 2017.

[13] A. A. Shah, "The Impact and Association among Innovation Types and Performance of Telecommunication Companies in Pakistan," 2018.

[14] R. Jain and T. Kailay, "A Dream of Cashless Society: A Myth or Reality! (Study of customers regarding the awareness and preference for plastic money)," International Journal of Scientific and Research Publications., 2018.

[15] Kamboh and Javaid Leghari, "Impact of cashless banking on profitibility: A case study of banking industry in Pakistan," A Research Journal of Commerce, Economics, and Social Sciences, pp. 82-93, 2016.

[16] Daneshgadeh and SevgiÖzkan Yıldırım, "Empirical investigation of internet banking usage: The case of Turkey. Procedia Technology," Procedia Technology 16, pp. 322-331, 2014.

[17] D. Awrey and K. van Zwieten, "The Shadow Payment System," 2016.

[18] E. Peiqi and O. Widjaja, "Electronic Non-Cash Payment Options in Malaysia," Journal of Southeast Asian Economies, vol. 33, no. 3, pp. 398-412, 2016.

[19] V. Dostov and P. Shust, "Cryptocurrencies: An unconventional challenge to the AML/CFT regulators?," Journal of Financial Crime, vol. 21, no. 3, pp. 249-263, 172014.

[20] B. Yahid, A. Shahbahrami and M. B. Nobakht, "Providing security for E-Wallet using E-Cheque," International Journal of Information Science and Management, vol. 11, no. SPL.ISS., pp. 85-96, 2013.

[21] "Survey for cashless India," [Online]. Available: https://www.surveymonkey.com/r/F7LSV9Z.

\section{Authors' Profiles}

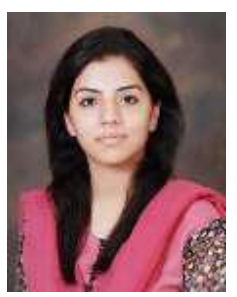

Sania Zafar Awan: Sania is currently studying MS in Computer Science from Institute of Business Administration, IBA. She has completed her Bachelor's in Computer and Information Systems from NED University of Science and Technology in 2017.

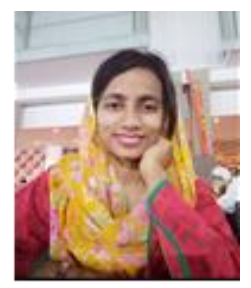

Sidra Riaz: Sidra is currently studying MS in Computer Science from Institute of Business Administration, IBA She has completed her Bachelor's in Computer Science from IBA in 2017.

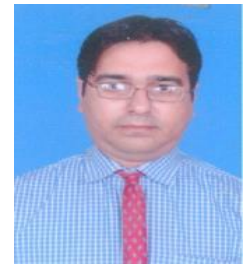

Waqas Mahmood: Waqas is a professor at IBA, he has completed MS in Economics and Finance from IoBM in 2012 an MS in Software Project Management from FAST in 2010. 


\section{Appendix A. Questionnaire}

- Your Age?

$\begin{array}{ll}\text { a. } & 18-24 \\ \text { b. } & 25-34 \\ \text { c. } & 35-44 \\ \text { d. } & 45-54 \\ \text { e. } & 55-64 \\ \text { f. } & 65-74 \\ \text { g. } & 75 \text { or older }\end{array}$

- $\quad$ Gender?

a. Male

b. Female

- Occupation
a. Employee
b. Self-Employed/Business
c. Other

- $\quad$ Monthly Income
a. Below 20,000
b. $\quad 20,000-40,000$
c. $\quad 40,000-60,000$
d. Above 60,000
e. Other

- If you currently have a bank account, which bank is it in? Tick all that apply

$\begin{array}{ll}\text { a. } & \text { HBL } \\ \text { b. } & \text { Standard Chartered } \\ \text { c. } & \text { MCB } \\ \text { d. } & \text { Alfalah } \\ \text { e. } & \text { UBL } \\ \text { f. } & \text { Meezan } \\ \text { g. } & \text { Dubai Islamic } \\ \text { h. } & \text { Al Barkah } \\ \text { i. } & \text { JS Bank } \\ \text { j. } & \text { Faysal } \\ \text { k. } & \text { Others }\end{array}$

- $\quad$ Are you in favor of commercial banks?
a. Strongly in favor
b. Somewhat in favor
c. Somewhat not in favor
d. Strongly not in favor

- Which payment method do you use least when buying products and services?
a. Credit Cards
b. Debit Cards
c. Cash
d. Other

- If you have selected other in previous question, please specify

- $\quad$ How often do you use mobile money to pay for goods and services?
a. $\quad 0-5$ times a day
b. 5-10 times a day
c. More than 10 times a day
d. Regular daily user

- How often do you use bankcards to pay for goods and services?
a. $\quad 0-5$ times a day
b. 5-10 times a day
c. More than 10 times a day
d. Regular daily user 
- Would you prefer digital money to pay for goods and services?
a. Cash
b. Digital Money
c. Others

- $\quad$ Are digital methods risky according to you?
a. Yes
b. No
c. I don't know

- Do you support Cashless Pakistan?
a. Yes
b. $\quad \mathrm{No}$
c. I don't know

- Which of the following do you know about? Tick all that applies
a. Phone banking services
b. Internet banking Services
c. JazzCash
d. Easypaisa
e. SimSim
f. Keenu Wallet
g. U-Paisa
h. None

- Which of the following have you used? Tick all that applies.

$\begin{array}{ll}\text { a. } & \text { Phone banking services } \\ \text { b. } & \text { Internet banking Services } \\ \text { c. } & \text { JazzCash } \\ \text { d. } & \text { Easypaisa } \\ \text { e. } & \text { SimSim } \\ \text { f. } & \text { Keenu Wallet } \\ \text { g. } & \text { U-Paisa } \\ \text { h. } & \text { None }\end{array}$

- If you use Uber/Careem what payment method do you prefer?
a. Credit/Debit card
b. Wallet top up
c. Cash
d. I don't use these services

- $\quad$ How do you prefer to pay your utility bills?
a. Internet banking
b. Cash
c. Others

- If you use a cashless method, do you think the current transaction methods are complicated?
a. Strongly Agree
b. Agree
c. Neutral
d. Disagree
e. Strongly Disagree

- Do you think lack of technical knowledge is a barrier to cashless Pakistan?
a. Strongly Agree
b. Agree
c. Neutral
d. Disagree
e. Strongly Disagree

- People do not use cashless technology so that they will not have to disclose their financial information. Do you agree?
a. Strongly Agree
b. Agree
c. Neutral
d. Disagree
e. Strongly Disagree 
- $\quad$ According to you, are cashless transactions convenient?
a. Strongly Agree
b. Agree
c. Neutral
d. Disagree
e. Strongly Disagree

- Do you think delayed reimbursement of failed transactions is a major reason why people avoid cashless transactions?
a. Strongly Agree
b. Agree
c. Neutral
d. Disagree
e. Strongly Disagree

- Do you think limits on cashless transaction is a major reason why people avoid cashless transactions?
a. Strongly Agree
b. Agree
c. Neutral
d. Disagree
e. Strongly Disagree

How to cite this paper: Sania Zafar, Sidra Riaz, Waqas Mahmood, " Conducing the Cashless Revolution in Pakistan Using Enterprise Integration", International Journal of Education and Management Engineering (IJEME), Vol.11, No.4, pp. 12-25, 2021. DOI: $10.5815 /$ ijeme.2021.04.02 